\title{
Allah Yang Esa Menurut Ajaran Kristen
}

\author{
Sperry Velmer Terok \\ Sekolah Tinggi Teologi Kalimantan \\ Korespondensi: sperryvterok@sttkalimantan.ac.id
}

\begin{abstract}
Abstrak
Alkitab menyatakan bahwa Allah sukar bahkan mustahil untuk dipahami (Ayb 11:7; Yes. 40:18), namun Dia dapat dikenal. Tuhan Yesus pernah menegaskan kebenaran penting tesebut kepada murid-murid-Nya: "Sekiranya kamu mengenal Aku, pasti kamu menganal Bapa-Ku. Sekarang ini kamu mengenal Dia dan kamu telah melihat Dia (Yoh. 14:7).” Mengapa Allah yang Esa itu sukar dipahami? Karena masalah dosa, pikiran pengetahuan dan bahasa manusia, namun bukan berarti manusia tidak dapat mengenal Allah. Pemahaman tentang Allah yang Esa dalam ajaran Kristen merupakan hal yang menantang. Supaya dapat menguraikan dan memahami Allah yang Esa dalam ajaran Kristen penulis menggunakan metode Deskriptif. Maksudnya untuk dapat mendeskripsikan suatu sistem pemikiran selanjutnya menginterpretasikan secara tepat. Adapun hasil kajian tulisan ini, bahwa eksistensi Allah yang esa dalam ajaran Kristen sangat jelas dilaporkan Alkitab; selanjutnya bahwa Allah yang Esa yang telah memperkenalkan diri sebagai Allah Tritunggal sangat jelas berdasarkan PL maupun PB. Allah Tritunggal yakni: Bapa, Anak (Yesus Kristus) serta Roh Kudus, ketiga-Nya sehakekat sekaligus setara. Akhirnya, bahwa setiap orang pasti dapat memahami dan mengenal-Nya, sejauh yang dikatakan Alkitab. Kunci memahami dan mengenal Allah yang Esa yakni terlebih dahulu meyakini Alkitab adalah Firman Allah. Kiranya pemahaman yang dimiliki setiap orang percaya dapat memberi makna secara pribadi, bagi orang lain, dan akhirnya di atas kedua kepentingan tersebut kemuliaan dan hormat bagi Allah sendiri.
\end{abstract}

Kata kunci: Allah, esa, pemahaman, eksistensi, Tritunggal.

\begin{abstract}
The Bible states that God is difficult and even impossible to understand (Job. 11:7; Isa. 40:18), but He can be recognized. Jesus The Lord once confirmed this important truth to His disciples: "If you have known me, you will know my Father too. And from now on you do know Him and have seen Him. (Joh. 14:7)." Why God seems difficult to understand? It is because of the sin's problem; the limitation of the human mind and understanding, but it does not mean that humans cannot recognize God. An understanding of the One God in Christianity is challenging. In order to describe and understand the One God in Christianity, the author uses descriptive methods. The intention is to be able to describe a system of thought in order to further interpret it precisely. As a result of the study of this paper, that the existence of One God in Christianity is clearly reported in the Bible; furthermore, the One God who has introduced Himself as a Trinity God is very clear both in Old Testament as well as in New Testament. The Trinity God: God the Father, God the Son, Holy Spirit, all three is one and equal. Finally, everyone can understand and recognize Him as far as the Bible says. The key to understand and recognize the One God is to believe the Bible is the Word of God in the first place. Then presume the understanding that every believer has can give meaning personally to others, and at last above these two interests, glory and honor to God, Himself.
\end{abstract}

Keywords: God, one, understanding, exist, Trinity. 


\section{PENDAHULUAN}

Fakta yang tidak dapat diragukan bahwa siapapun kita, tua atau muda, laki-laki atau perempuan, miskin atau kaya, terpelajar atau tidak, tinggal di kota atau di desa, maka sebagai manusia yang normal pastilah merindukan pengetahuan tentang Allah Yang Esa.

Dalam pertemuan formal ataupun non formal misalnya, seminar-seminar, diskusi-diskusi atau dialog-dialog, bahkan dalam percakapan secara pribadi tidak jarang pokok yang dibaicarakan adalah tentang Allah Yang Esa. Pada sisi yang lain, apabila mencermati dan mengamati peristiwa-peristiwa sosial di tengah masyarakat di sana-sini terjadi peperangan, pembunuhan, pemerkosaan, ketidakadilan dan lain sebagainya; jika memperhatikan peristiwaperistiwa itu timbul pertanyaan, apakah Allah Yang Esa benar-benar ada serta memiliki otoritas dalam segala dan apakah segala peristiwa yang terjadi dalam kehendak dan kontrol dari Allah Yang Esa?

Orang Kristen tidak pernah beranggapan bahwa dalam segala kejadian atau peristiwa Dia menutup mata, sebaliknya dalam segala sesuatu yang terjadi semua ada dalam kedaulatan Allah Yang Esa. Selanjutnya, apabila seorang berangapan bahwa saat-saat tertentu Allah yang Esa berhenti dalam kedaulatan-Nya, maka orang tersebut adalah orang yang belum memilik pemahaman tentang pribadi dari Allah Yang Esa. Bagaimanakah pemahaman Allah Yang Esa menurut ajaran Kristen? Apakah dasar atau landasan untuk dapat memahami Allah Yang Esa? Dapatkah orang mengenal Allah Yang Esa? Adapun yang menjadi tujuan dari penulisan artikel ini yakni, supaya dapat menjawab pertanyaan atau permasalahan.

\section{METODE}

Adapun metode yang dipergunakan dalam tulisan ini adalah metode deskriptif. Sehubungan dengan definisi metode deskriptif, Usman Rianse melalui karyanya yang berjudul Metode Penelitian mengatakan:
Metode Penelitian Deskriptif bertujuan untuk menggambarkan secara tepat sifat-sifat suatu individu, keadaan, gejala atau hal-hal yang khusus dalam masyarakat. Penelitian jenis ini bisa sudah ada hipotesis, namun dapat pula belum ada hiptesis, tergantung dari ada tidaknya pengetahuan tentang masalah yang diteliti. Penelitian deskriptif dapat pula menggunakan data kuantitatif yang dapat dipakai untuk menguji hipotesis-hipotesis. Jenis-jenis metode dalam penelitian deskriptif terdiri dari studi kasus, survei, penelitian pengembangan, dan penenlitian lanjutan. ${ }^{1}$

Selanjutnya, Zaluchu menegaskan pilihan terhadap metode deskriptif pada umumnya dipakai jika peneliti ingin membeberkan informasi mengenai permasalahan yang sedang diteliti. Sejumlah alat dapat dipakai untuk menjelaskan seperti tabel, grafik, gambar dan bagan. Tujuan utamanya adalah mempertegas situasi atau kondisi tertentu. ${ }^{2}$ Jadi metode deskriptif digunakan supaya dapat mendeskripsikan suatu sistem pemikiran dan penulis selanjutnya menginterpretasikan secara cermat dan tepat.

\section{PEMBAHASAN}

\section{Eksistensi Allah Yang Esa}

Eksistensi tentang Allah yang Esa merupakan fakta yang diajarkan dalam keyakinan kaum Yahudi, Kristen serta Muslim. Bagaimana pemahaman tentang Allah yang Esa dalam ajaran Kristen? Pokok inilah yang akan diuraikan dalam tulisan ini. Dengan maksud supaya melalui uraian ini pemahaman yang benar tentang Allah yang Esa dalam keyakinan Kristen semakin mantap; bahkan seiring dengan pemahaman yang ada, sekaligus dapat mempertanggungjawabkan atau memberi jawab kepada orang lain yang memerlukan.

${ }^{1}$ Usman Rianse, Metodologi Penelitian Sosial dan Ekonomi: Teori dan Aplikasi (Bandung: Alfabeta CV), 26-27.

${ }^{2}$ Sonny Eli Zaluchu, "Strategi Penelitian Kualitatif Dan Kuantitatif Di Dalam Penelitian Agama," Evangelikal: Jurnal Teologi Injili dan Pembinaan Warga Jemaat 4, no. 1 (January 31, 2020): 28, https://journal.sttsimpson.ac.id/index.php/EJTI/article/v iew/167. 
Berbicara pokok tentang Allah Setidaktidaknya hal ini merupakan perkara yang jelas, bahwa Dia pribadi yang kekal sekaligus mampu melakukan segala hal! Ia Mahakuasa! Semua yang terjadi adalah dalam kedaulatan dan seizin Dia. Jika demikian apa masalahnya? Masalahnya yakni bahwa banyak orang yang tidak menyukai Dia. ${ }^{3}$

Para teolog Kristen secara khusus yang membidangi ilmu perbandingan agama dan juga para pekabar Injil senada dan mengakui bahwa ide tentang Allah bersifat universal di dalam setiap suku bangsa. Ide tentang Allah ini bahkan ditemukan pada ajaran suku-suku dan bangsa-bangsa yang sangat jauh dari peradaban.

Menaanggapi kenyataan bahwa keberadaan Allah adalah bersifat universal adalah sejalan dengan apa yang didefinisikan oleh Spinoza yang dikutip oleh Henry C. Thiessen, dalam bukunya Teologia sistematika, sebagai berikut:

Spinoza mendefinisikan Allah sebagai substansi yang mutlak dan universal, penyebab sejati dari segala sesuatu yang ada, dan bukan saja sekedar penyebab segala keberadaan, tetapi Allah sendiri merupakan penyebab segala keberadaan sehingga setiap benda yang ada merupakan modifikasi Allah saja. $^{4}$

Memperhatikan uraian di atas, bukan berarti bahwa sama sekali tidak ada orang yang menyangkali keberadaan Allah, juga tidak berarti bahwa tidak ada sejumlah besar orang yang tinggal di kota-kota atau negara-negara Kristen yang menyangkal keberadaan Allah sebagaimana yang Ia wahyukan melalui atau dalam Alkitab. Allah yang keberadaan dan kesadaran diri-Nya sepenuhnya bergantung pada diri-Nya sendiri, yang sempurn dan kekal, yang mengerjakan segala sesuatu menurut rencana yang terlebih dahulu telah Ia tetapkan.

Apabila berbicara tentang pemahaman Allah Yang Esa menurut ajaran Kristen, secara khusus menguraikan keberadaan diri Allah maka bagi kaum Kristen selalu melandaskan pada Alkitab. Selanjutnya apabila menyingung tentang karya-

${ }^{3}$ Ds. P.B. Suurmond, Allah Itu Berkuasa Tetapi Bagaimana? (Jakarta: BPK. Gunung Mulia, 1996), 31-32.

${ }^{4}$ Henry C. Thiessen, Teologi Sistematika (Malang: Gandum Mas, 1993), 36. karya dogmatika atau teologi sistematika di kalangan Kristen, pada umumnya yang dibicarakan mula-mula dimulai dengan pokok tentang Allah. Bahkan umumnya prosedur ini selalu dianggap sebagai prosedur yang paling logis serta menunjuk kearah yang benar. Hubungan dengan hal ini, sudah tentu ada alasan yang kuat, mengapa karena apabila berbicara tentang masalah dogmatika atau teologi idealnya dimulai dengan ajaran/doktrin tentang Allah.

Adapun salah satu alasan yang sangat prinsip sebagaimana yang disampaikan oleh Louis Berkhof:

Teologi adalah pengetahuan tentang Allah, yang
darinya, olehnya, melaluinya, dan baginya segala
sesuatu berada. Hubungan dogmatika haruslah
dimulai dengan doktrin tentang Allah, bahkan kita
boleh berharap bahwa dogmatika secara
keseluruhan adalah telaah tentang Allah.

Paul Enns menandaskan istilah teologi, berasal dari kata Yunani theos - Allah dan Logos kata/percakapan, oleh karena itu, teologi adalah suatu percakapan tentang Allah. Teologi pada umumnya dimengerti sebagai istilah yang memiliki arti yang luas yaitu meliputi keseluruhan aspek kepercayaan Kristiani (studi tentang Kristus, Roh Kudus, Malaikat, dll). ${ }^{6}$ Selanjutnya berkenaan dengan apa yang dipelajari melalui ilmu teologi tersebut terdapat satu landasan yang tidak boleh diabaikan bahwa teologi yang dipelajari semakin jelas dan mantap, dan yang terpenting adalah benar berdasarkan Alkitab. Selanjutnya bagi kalangan Kristen mengakui bahwa ada ahli agama yang mengira, bahwa mereka dapat membuktikan adanya Allah. Memang sejak zaman dahulu orang yang beragama merasa dan menyadari bahwa dalam dirinya ada pengertian, pengetahuan atau pemahaman tentang Allah, tetapi dipihak yang lain ada juga ajaran yang mengancam kepercayaan kepada Allah yang benar itu.

${ }^{5}$ Louis Berkhof, Teologia Sistematika Doktrin Allah (Jakarta: Lembaga Reformed Injili Indonesia, 1994), 7.

${ }^{6}$ Paul Enns, The Moody Handbook of Theology: Buku Pegangan Teologi (Malang: Literatur SAAT, 2003), 223. 
Bagi kaum Kristen memercayai bahwa, Allah tidak terbatas oleh karena itu, suatu definisi yang lengkap tentang Allah merupakan suatu kemustahilan. Walaupun demikian, tentulah definisi tentang Allah itu dapat dibuat sejauh pengenalan seseorang kepada Dia. Berikut ini akan dipaparkan beberapa definisi tentang Allah dan diakhiri dengan suatu argument Alkitabiah tentang keberadaan Allah. Buswell mendefinisikan Allah sebagai berikut: "Allah adalah roh, tidak terbatas, kekal, tidak berubah dalam diri-Nya, kebijaksanaan-Nya dan kebenaran-Nya."7 Selanjutnya definisi lain disampaikan oleh Koeksema, sebagai berikut:

Allah adalah pribadi yang Esa, tak terbagi, mutlak, rohani semata-mata, memiliki kesempurnaan yang tak terbatas, sepenuhnya imanen dalam seluruh dunia, namun pada hakekatnya transenden terhadap segala yang ada. ${ }^{8}$

Sebagaimana pada bagian terdahulu telah disingung bahwa untuk membuat suatu rumusan atau definisi tentang Allah, itu bukan sesuatu yang mudah, tetapi setelah mencermati beberapa definisi di atas, maka dapat disimpulkan secara singkat bahwa, Allah adalah pribadi yang tidak terbatas, kekal, tidak berubah dalam diri-Nya dan bahkan sempurna; dan dalam Dia segala sesuatu bersumber, terpelihara dan akan berakhir.

Sesudah rumusan tentang Allah dipahami, sejauh manakah argumen Alkitab berbicara tentang eksistensi atau keberadaan Allah itu sendiri? Seorang Kristen yang sejati sudah pasti percaya bahwa Firman Allah itu sungguh diilhamkan oleh Allah, yang walaupun dalam rentang waktu yang panjang dan melibatkan sangat banyak pribadi atau person sebagai penulis, namun sekali lagi bahwa proses penulisan adalah dalam rancangan Allah sendiri (dalam kontrol Roh Kudus).

Bagi kalangan Kristen, eksistensi Allah merupakan pra anggapan penting dalam teologi.

${ }^{7}$ James Oliver Buswell, A Systematic Teology of The Christian Religion (Grand Rapids: Zondervan Publishing House, 1978), 30.

${ }^{8}$ Herman Hoeksema, Reformed Dogmatics (Grand Rapids: Reformed Free Publishing Association, 1996), 60.
Pembicaraan tentang pengetahuan akan Allah tidaklah masuk akal, kecuali jika dapat mengendalikan bahwa Allah itu ada. Namun harus dipahami dan disadari bahwa pra anggapan teologi Kristen adalah sesuatu yang sangat pasti.

Pandangan ini bukanlah semata-mata berpendapat bahwa ada sesuatu, suatu ide atau gagasan, suatu kuasa atau suatu kecenderungan terarah yang dapat disebut sebagai Allah, tetapi sesungguhnya ada suatu pribadi yang keberadaannya adalah bersumber pada diri-Nya sendiri. Dia adalah pribadi yang tidak dipengaruhi. Suatu keberadaan berpribadi yang merupakan asal mula dari segala sesuatu yang jauh melampaui segala ciptaan, akan tetapi pada saat yang sama juga hadir dalam segala bagian ciptaan-Nya.

Ajaran Kristen juga menerima kebenaran tentang Allah itu dengan iman. Iman ini bukanlah iman yang buta, melainkan iman yang berdasarkan bukti atau argumen, dan argumen itu ditemukan dalam Alkitab sebagai Firman Allah. Tetapi dalam anggapan ini Alkitab tidak berusaha membuktikan bahwa Allah ada. Hal mana disebabkan, karena sepanjang Alkitab adanya Allah sudah dianggap pasti. Sebagaimana Alkitab, Perjanjian Lama dalam Kejadian 1:1, berbunyi: "Pada mulanya Allah ...." Selanjutnya bagian lain yang berbicara tentang keberadaan Allah terdapat dalam Yohanes 1:1-2.

Dari teks tersebut dapat dipahami bahwa tidak ada penulis Alkitab yang coba membuktikan bahwa Allah ada. Dan memang di seluruh dunia percaya bahwa Allah ada. Kepercayaan itu memang diletakkan Allah dalam hati manusia. Pemazmur yakni Daud, pernah mengatakan bahwa, "Orang bebal berkata dalam hatinya: "Tidak ada Allah" (Mzm. 14:1). Tetapi bagi kalangan Kristen diajarkan, kalau pun kita ingin mendapatkan bukti bahwa Allah itu ada maka kita harus melihat secara nyata kepada pribadi Yesus Kristus

Kenyataan Allah ada dibuktikan dalam sifat kesucian Yesus Kristus. Alkitab juga membuktikan bahwa Allah benar-benar ada, sebab tanpa pertolonga Allah manusia tidak mungkin dapat menulis Alkitab (2 Tim. 3:16; 2 Pet. 1:21). Di samping itu, pekerjaan Yesus 
Kristus lebih menegaskan bahwa benar Allah itu ada. Lebih lanjut lagi jemaat Kristus juga membuktikan bahwa Allah itu ada. ${ }^{9}$

Mencermati dan memahami uraian di atas, maka secara jelas dan mantap bahkan dengan tegas dapat dipahami bahwa, ternyata kepercayaan atau iman Kristen menerima eksistensi Allah yang Esa bukanlah dengan iman yang buta tetapi dilandaskan pada Alkitab sebagai Firman Allah.

\section{Konsep Biblikal Tentang Allah Yang Esa}

Apakah artinya Allah Yang Esa itu? Bagi kalangan umat Kristen pengajaran bahwa Allah Yang Esa atau Allah itu Esa merupakan suatu hal yang tidak asing lagi. Hal mana disebabkan karena ajaran ini memang didasarkan dari Alkitab atau Firman Allah. Hubungan dengan hal ini, menurut R. A. Finlayson dan J. M. Houston berpendapat bahwa, "Allah dalam pengertian Kristen, Alkitab adalah satu-satunya sumber ajaran tentang Allah, dalam Alkitab kita menemukan penyataan Allah tentang diri-Nya sendiri." ${ }^{10}$

Adapun alasan dari bagian ini adalah untuk memberikan penjelasan yang Alkitabiah, bahwa sesungguhnya umat Kristen sangat konsisten dengan pengajaran bahwa Allah itu Esa. Allah Yang Esa berarti hanya ada satu Allah saja, dan bahwa sifat dasar atau watak Allah tidak dapat dipisahkan atau dibagi. Firman Allah sangat tegas mengajarkan kepercayaan ini. Mengomentari hal ini, Henry C. Thiessen, menegaskan bahwa Allah itu Esa adanya merupakan kebenaran sejati Perjanjian Lama (Ul. 4:35, 39; 1 Raj. 8:60; Yes. 45:4, 6). Kebenaran yang sama juga sering diajarkan dalam Perjanjian Baru (Mrk. 12:29-30; Yoh. 17:3; 1 Kor. 8:4-6; 1 Tim 2:5). ${ }^{11}$ Selanjutnya, Harun Hadiwijono menambahkan jikalau Alkitab merumuskan pengakuan iman umat Allah tentang Tuhan Allah maka rumusan itu

${ }^{9} \mathrm{~J}$. Wesley Brill, Dasar Yang Teguh (Bandung: Yayasan Kalam Hidup, 1994), 31.

${ }^{10}$ R. A. Finlayson dan J. M. Houston, "Allah” dalam Ensiklopedi Alkitab Masa Kini (Jakarta: Yayasan Komunikasi Bina Kasih/OFM, 1994), I:33.

${ }^{11}$ Thiessen, Teologia Sistematika, 137. diungkapkan demikian: "Dengarlah, hai orang Israel: Tuhan itu Allah kita, Tuhan itu Esa! Kasihilah Tuhan, Allahmu, dengan segenap hatimu dan dengan segenap jiwamu dan dengan segenap kekuatanmu (Ul. 6:4-5).”

Penting sekali dipahami bahwa ucapan ini disampaikan oleh nabi Musa kepada bangsa Israel pada saat Musa akan meninggal. Tetapi ucapan itu bukanlah hasil rumusan pemikiran Musa secara teori belaka, melainkan ini merupakan bagian dari Firman Allah yang disampaikan kepada bangsa pilihan Allah itu melalui nabi Musa, setelah Musa berpengalaman memimpin bangsa Israel keluar dari tanah Mesir. Lebih lanjut lagi bahwa Tuhan atau Yahweh itu disebut Esa. Ungkapan yang diterjemahkan dengan "Tuhan itu Allah kita, Tuhan itu Esa," dalam bahasa aslinya adalah Yahweh elohenu Yahweh ekhad." ${ }^{\prime 2}$ Menanggapi ayat tersebut, Hadiwijono mengatakan bahwa Yahweh elohenu Yahweh ekhad dapat diterjemahkan seperti yang ada dalam terjemahan baru, sebagai berikut, "Tuhan adalah Allah kita, Tuhan saja," artinya bahwa tiada Allah lain, yang menjadi Allah kita, kecuali Tuhan. Bagaimanapun kata ekhad diterjemahkan (dengan "Esa" atau "saja") di dalam hubungan pernyataan ini teranglah bahwa: "Kata ekhad itu menunjuk kepada kedudukan Tuhan yang khas terhadap alah-alah lain, dan bertentangan dengan Allah yang lain, yang dimiliki bangsa-bangsa disekitar Israel." 13

Pengertian tentang Allah Yang Esa, sebagaimana yang diajarkan oleh Musa dalam Taurat terdapat juga dalam Perjanjian Baru, hal ini umpamanya jelas dari perkataan Tuhan Yesus sendiri sebagai berikut: "Inilah hidup yang kekal itu, yaitu bahwa mereka mengenal Engkau satusatunya Allah yang benar, dan mengenal Yesus Kristus yang telah Engkau utus (Yoh. 17:3).”

Adapun kata-kata yang diterjemahkan dengan "satu-satunya Allah yang benar" adalah, "(Ton monon alethian Theon)." " Namun pernyataan tersebut dapat juga diterjemahkan

\footnotetext{
${ }^{12}$ Biblia Hebraica Stuttgartensia (Stuttgart: Deutche Biblegsellchaft, 1990), 297.

${ }^{13}$ Harun Hadiwijono, Iman Kristen (Jakarta: PT. BPK. Gunung Mulia, 1995), 99.

${ }^{14}$ Lembaga Alkitab Indonesia, Perjanjian Baru IndonesiaYunani (Jakarta: Lembaga Alkitab Indonesia, 1994), 797.
} 
dengan "Allah yang satu dan benar" atau "satusatunya yang benar-benar Allah." "Dengan demikian maka jelaslah bahwa menurut Perjanjian Baru tidak ada Allah lain kecuali Tuhan Allah." 15

Memahami uraian atau penjelasan di atas, maka secara jelas dapat dimengerti bahwa berdasarkan Alkitab baik Perjanjian Lama maupun Perjanjian Baru menyakini kalau hanya ada satu Allah; atau dengan perkataan yang lain bahwa Allah Yang Esa adalah doktrin yang Alkitabiah. Jadi percaya akan adanya Allah Yang Esa, memang sangatlah baik, tetapi jika hanya berhenti disitu saja, belum cukup. Pengakuan bahwa Tuhan Allah adalah satu atau Esa, membawa konsekuensi. Konsekuensi itu tidak lain dari pada menaati perintah Tuhan Allah sendiri yakni mengasihi Tuhan Allah dengan segenap hati, segenap jiwamu dengan segenap akal budimu dan segenap kekuatanmu dan sekaligus mengasihi sesamamu seperti diri sendiri. Singkatnya secara lahir dan batin kehidupan umat Allah haruslah dipersembahkan kepada Tuhan, dengan demikian tidak akan mengabaikan sesamanya.

\section{Allah Yang Esa Memperkenalkan Diri Sebagai Tritunggal}

\section{Makna Istilah Tritunggal}

Istilah Tritunggal menurut Kamus Besar Bahasa Indonesia artinya yakni, "Kesatuan dari tiga hal (orang). Contoh: Kecamatan ialah camat, kepolisian, dan angkatan darat (Tentara)."16 Selanjutnya kata Tritunggal ini dalam bahasa Inggrisnya adalah trinity, hal ini yang seperti dikatakan oleh John M. Echols, "Kata trinity artinya KB. (jamak adalah trinities) Trinitas, Tritunggal (Holy) trimurti." ${ }^{17}$ Ditambahkan dalam Alkitab Hidup Berkelimpahan, Seri: Life Aplikation Study Bible, istilah Trinitas merupakan sebuah gambaran tentang hubungan

\footnotetext{
${ }^{15}$ Hadiwijono, Iman Kristen, 102.

${ }^{16}$ Departemen Pendidikan dan Kebudayaan, Kamus Besar Bahasa Indonesia (Jakarta: Balai Pustaka, 1991), 1072.

${ }^{17}$ John M. Echols, dan Hasan Sadily, Kamus InggrisIndonesia (Jakarta: PT. Gramedia Pustaka Utama, 1983), 1072.
}

yang unik antara Allah Bapa, Putera, dan Roh Kudus." ${ }^{18}$ Lebih lanjut lagi menanggapi arti kata ini M. E. Manton mengatakan bahwa kata ini berbicara tentang satu Allah dalam tiga oknum, yaitu Bapa, Anak, dan Roh Kudus. Doktrin ini secara tidak langsung disebut dalam Perjanjian Lama (Roh aktif sewaktu penciptaan, dan oknum yang berbeda dengan Tuhan Allah dan juga berbeda dengan Roh-Nya telah berbicara dalam kitab Yesaya. Misalnya Yesaya 48:16; 61:1). ${ }^{19}$ Kata "Oknum" dalam bahasa Indonesia bisa juga berarti "cara berada" atau "sesuatu" atau juga "hal." Sehubungan dengan hal ini, Robert Crossley dalam bukunya Tritunggal Yang Esa mengatakan bahwa "Bagi orang Yunani biasanya memahami kata hypostasis, orang Romawi memahami kata pesona dan orang Inggris memahami kata person." 20

Mencermati semua uraian di atas dapat dipahami bahwa istilah Tritunggal merupakan suatu kata benda yang berarti, dalam satu Allah terdapat tiga oknum atau cara berada. Adapun di dalam ajaran kaum Kristen tiga oknum yang dimaksud adalah Bapa, Anak (Yesus Kristus) dan Roh Kudus.

\section{Sejarah Doktrin Tritunggal}

Sejak abad pertama, Gereja yang masih muda telah dihadapkan dengan berbagai ragam persoalan. Salah satu persoalan yang sangat serius yakni pergumulan untuk merumuskan kepercayaan mengenai Tuhan Allah.

Robert P. Lightner dalam salah satu karyanya yang berjudul EvangelicalTeology berkata bahwa "Salah satu doktrin mendasar tentang iman Kristen yang bersejarah adalah tentang Tritunggal. $^{21} \quad$ Sebagaimana telah disinggung pada bagian terdahulu bahwa istilah Tritunggal tidak ada di dalam Alkitab, akan tetapi istilah ini adalah benar-benar timbul dari kitab suci (Alkitab). Kalangan teologi Kristen memakai

${ }^{18}$ Alkitab Penuntun Hidup Berkelimpahan Seri: Life Aplication Study Bible. (Malang: Gandum Mas, Cet. II, 2016), 2242.

${ }^{19}$ Manton, Kamus Istilah Teologia, 143.

${ }^{20}$ Robert Crossley, Tritunggal Yang Esa (Jakarta: Yayasan Komunikasi Bina Kasih/OMF, 1992), 40.

${ }^{21}$ Lightner, Evangelical Teology, 49. 
istilah ini setelah melalui perdebatan dan bahkan pergumulan yang menyita cukup banyak waktu. Bagaimanakah sejarah doktrin Tritunggal dalam kalangan umat Kristen?

Berawal pada abad mula-mula (abad 1 dan 2), beberapa tokoh gerejan telah coba memberikan definisi tentang Allah, misalkan Yustinus Martir, Filsuf Kristen pertama, ia berpendapat bahwa Allah dalam keadaan sebagai Bapa, yang adalah baik dan benar, yang juga disebut raja itu, adalah pencipta segala sesuatu, Ia tidak terhampiri, tidak bernafsu, dan tidak dapat disuap dengan korban-korban. Karena Ia pencipta segala sesuatu maka Allah adalah hidup, pemilik dan penyebab segala sesuatu. ${ }^{22}$ Akan tetapi pendapat Yustinus Martir justru banyak dipengaruhi oleh filsafat Yunaninya; salah satu pemikiranya bahwa oknum kedua dalam Tritunggal, "Kristus adalah Logos yang menjadi pesuruh (angelos) dan wakil/hamba (huperentes) dari Bapa."23 Dengan demikian seakan-akan Kristus itu dibawah satu tingkat dari Bapa.

Tokoh Kristen yang kedua adalah Irenius (140-195) berasal dari Smirna, seorang murid Polycarpus. Pandangannya tentang Trinitas bisa dikatakan lebih Injili. Ia mengatakan, "bahwa sesungguhnya Bapa, Anak, dan Roh Kudus memiliki kodrat Ilahi," sangat disayangkan bahwa ia tidak banyak menggarap kEsatuan ketiga oknum tersebut.

Teolog lain yang cukup berpengaruh adalah Tertulianus (160-222), berasal dari Afrika Utara, setelah menjadi Kristen ia menjadi pembela agama yang sangat gigih. Adapun teolog ini dianggap sebagai teolog yang besar sekali pengaruhnya bagi perumusan ajaran Tritunggal. Hal ini disebabkan karena, "dari padanyalah istilah substansi atau zat atau persona atau pribadi dikenakan pada ajaran Tritunggal." 24 Memang harus diakui bahwa dalam perumusan ajaran tentang Tritunggal banyak sekali menimbulkan kesalapahaman, akan tetapi berawal dari sumbangan pikiran Tertulianus inilah membawa umat Kristen kepada suatu

\footnotetext{
${ }^{22}$ Bambang Broto Sudjaly, Sejarah Dogma Trinitas (Yogyakarta: Taman Pustaka Kristen, t. t.), 30.

${ }^{23}$ Sudjaly, Sejarah Dogma, 30.

${ }^{24}$ Hadiwijono, Iman Kristen, 108.
}

pemahaman yang jelas hubungan dengan ajaran Tritunggal atau Trinitas.

Filsuf atau teolog lain yang penting dalam sejarah Tritunggal yakni, Origen. Pandanganya banyak dipengaruhi oleh lingkungan Romawi (Gnostisisme dan filsafat mengenai roh-roh setengah ilahi). Selanjutnya pandanganya tentang Tritunggal dapat membahayakan pemikiran khas Kristen, karena menempatkan posisi Kristus lebih rendah sedikit dari pada Bapa." ${ }^{25}$ Karena ia berasumsi bahwa dari Bapa atas kedaulatan Bapa, sehingga kedudukan Anak sudah jelas lebih rendah atau di bawah Bapa. Walaupun demikian Gereja pada zamanya sangatlah menghormati Origen sehingga ia disebut sebagai bapak Gereja.

Pertikaian terus berlangsung dan kata sepakat tentang Tritunggal belum dapat disimpulkan. Setelah Origen seorang uskup bernama Alexander tidak merasa puas dengan perkataan Origen, karena menurut Alexander "Logos diartikan sama seperti pandangan Yohanes dalam pendahuluan Injilnya dan sama juga dengan Irenius, bahwa Logos sendiripun adalah Allah sedari kekal." ${ }^{\text {26 }}$ Akibat perselisihan yang merambat, yang mempersoalkan relasi Logos dengan Allah, dan karena berdiri pada sisi yang minoritas, akhirnya Atanasius mengalami pengalaman beberapa kali dibuang dan dikucilkan.

Melihat keadaan gereja yang terus dalam perselisihan, maka kaisar Cornelius Agung memprakarsai suatu pertemuan dengan tujuan untuk memulihkan keadaan. Pada tahun $325 \mathrm{M}$ diselenggarakan sebuah konsili di Nicea. Di Nicea itulah terbentuk sebuah rumusan tentang Trinitas. Adapun rumusan itu sebagaimana yang kita kenal dengan sebutan "pengakuan iman Konsili Nicea."

Meskipun konsili di Nicea sudah selesai ternyata perdebatan belum juga reda. Tahun 381 M pada saat kaisar Theodocius Agung menjadi kaisar, maka diadakanlah konsili Constantinopel. Dalam konsili ini dirumuskan bahwa Bapa dan Anak seta Roh Kudus adalah

\footnotetext{
${ }^{25}$ Stephen Tong, Allah Tritunggal (Jakarta: Lembaga Reformed Injili Indonesia, 1993), 88.

${ }^{26}$ L. Berkhof dan I. H. Enklaar, Sejarah Gereja (Jakarta: BPK Gunung Mulia, 1992), 53.
} 
sehakekat. Rumusan tentang Allah Tritunggal yang dimaksud sebagaimana yang tertuang dalam pengakuan iman Konsili Constantinopel.

Setelah konsili Constantinopel masih terjadi pertikaian dan masalah yang diangkat yakni, bagaimana hubungan antara kemanusiaan dan keilahian yang ada pada Kristus belum disepakati. Pertikaian terus berlangsung antara Cyrillus dan Nestorius (412-428 M), akhirnya pertikaian itu dapat diselesaikan di konsili Chalcedon tahun $451 \mathrm{M}$. Disanalah dibuat jalan tengah untuk mengambil keputusan yang disepakati bahwa kedua tabiat Kristus tak terbagi dan terpisah tetapi juga tak tercampur dan tak berubah. Sejak itulah doktrin Tritunggal diterima dengan baik oleh gereja dan menjadi doktrin yang penting, dan barangsiapa yang tidak menerima Tritunggal dianggap bidat dan tidak termasuk dalam gereja sejati.

Sebagaimana dalam ajaran agama lainya, pada dasarnya mereka merasa bahwa ajaran tentang Allah adalah hal yang penting. Demikian juga bahwa hal yang sama berlaku bagi umat Kristen.

\section{Fakta Biblikal Tentang \\ Allah Yang Esa sebagai Tritunggal}

Asas pengajaran tentang Allah Yang Esa memperkenalkan diri sebagai Tritunggal adalah suatu pengajaran yang sangat berlawanan dengan ajaran yang mengatakan bahwa ada banyak Allah, dan berlawanan juga dengan pengajaran yang berpendapat bahwa ada tiga Allah (konsep Tritunggal yang salah).

Sesungguhnya hal ini merupakan satu rahasia yang tidak dapat dimengerti dengan sejelas-jelasnya, sebagaimana yang diungkapkan John M. Frame, "Allah dapat dikenal dan tidak dapat dipahami secara tuntas." ${ }^{27}$ Apalagi pengertian itu diteropong melalui kaca mata akal atau pikiran manusia. Akan tetapi hal Allah Yang Esa sebagai Tritunggal ini diajarkan kepada kita melalui Alkitab, walaupun harus diakui bahwa ajaran tentang istilah serupa dapat ditemukan dalam doktrin-doktrin dari agama

\footnotetext{
${ }^{27}$ John M. Frame, Doktrin Pengetahuan Tentang Allah I: Objek Pengetahuan dan Justifikasi Pengetahuan (Malang: SAAT, 1999), 28.
}

yang lain, misalkan dalam ajaran agama Hindu, Budha, dan lain sebagainya.

Apakah yang dimaksud dengan Allah Yang Esa memperkenalkan diriNya sebagai Tritunggal? Ketiga-tiganya tidak terpisahkan satu dengan yang lain, namun berbeda-beda juga? Apakah artinya semua itu? Apakah ada artinya bila Allah Tritunggal dijelaskan menurut jalan pemikiran yang modern? Dalam ajaran Kristen tidak jarang ditemukan pengajaran-pengajaran yang keliru tentang doktrin ini, karena harus diakui bahwa ada beberapa sekte yang sangat keliru mengajarkan tentang Allah dan Yesus Kristus serta Roh Kudus itu. Adapun dalam pengajaran Kristen istilah Tritunggal itu terdapat perbedaan-perbedaan yang sangar prinsip dan sudah barang tentu tidak sama dengan apa yang diimani oleh kalangan Kristen.

Satu hal yang penting untuk selalu diingat dan dipahami, bahwa berbicara tentang Tritunggal Yang Esa bukan hanya membicarakan suatu ajaran teologis, tetapi bahwa topik ini para pemikir sedang membicarakan tentang Allah yang kebenaran-Nya diluar jangkauan pikiran manusia. Selanjutnya apa yang diketahui tentang Allah hanyalah apa yang diungkapkan atau diberitahukan-Nya. Itulah sebabnya pembahasan bagian ini akan didasarkan pada Alkitab. Bagi kalangan Kristen mengakui bahwa kata Tritunggal atau Trinitas bukanlah istilah Alkitab, karena istilah Tritunggal memang tidak ada dalam Alklitab. Akan tetapi bukan berarti karena tidak ada dalam Alkitab lalu tidak bisa dipakai, sebaliknya istilah ini bisa dipergunakan karena bermanfaat untuk menerangkan doktrin (ajaran) yang sulit. "Doktrin Tritunggal ini timbulnya dari Kitab Suci, jadi merupakan ajaran yang Alkitabiah." ${ }^{28}$ Selanjutnya hubungan dengan doktrin Tritunggal ini, Henry C. Thiessen menyatakan bahwa dalam teologia Kristen:

Istilah Tritunggal atau Trinitas berarti bahwa ada tiga oknum kekal dalam hakekat ilahi yang satu itu, yang masing-masing dikenal sebagai Allah Bapa, Allah Anak, dan Allah Roh Kudus. Tiga oknum ini dapat dikatakan sebagai tiga kepribadian Allah. Kita menyembah Allah Tritunggal. ${ }^{29}$

\footnotetext{
${ }^{28}$ Ryrie, Teologi Dasar I, 68.

${ }^{29}$ Thiessen, Teologia Sistematika, 138.
} 
Lebih lanjut lagi, Robert P. Lightner menambahkan secara tegas bahwa, "Para teolog injili merangkul ajaran ketritunggalan Allah karena pengajaran Kitab Injil secara keseluruhan." ${ }^{30}$

Memang pada saat semua yang dinyatakan oleh Alkitab digabungkan, ada satu penekanan dalam keanekaragaman dan kesatuan di dalam Allah. Allah dilihat sebagai satu dalam tiga dan tiga dalam satu. Jadi Alkitab tegas menyatakan bahwa hanya ada satu Allah saja. Dengan demikian, hubungan dengan ajaran tentang Allah dalam agama Kristen menganut paham monoteisme dan bukan triteisme atau politheisme.

Sejauh manakah penyataan Allah tentang doktrin Tritunggal ini? Apakah bukti-bukti Alkitab yang mendukung doktrin ini? Kiranya melalui bukti-bukti dari Pejanjian Lama dan Perjanjian Baru berikut ini mengantar pikiran kita pada suatu pemahaman yang jelas dan mantap sehubungan dengan masalah Tritunggal Yang Esa.

\section{Bukti Perjanjian Lama (PL)}

Dalam PL terdapat gambaran-gambaran tentang Tritunggal, namun yang ditekankan adalah hal kesatuan Allah. Penyataan yang jelas dan lengkap tentang Tritunggal sebagaimana terdapat dalam Perjanjian Baru (PB). Akan tetapi berbicara tentang gambaran ini, maka kita sangat perlu memahami kedua perjanjian tersebut.

Bukti PL berbicara tentang ajaran Tritunggal mula-mula terlihat dalam kata-kata yang berbentuk jamak untuk Allah. Kata Elohim adalah sebuah bentuk jamak yang adalah khas Perjanjian Lama. Secara umum kata ini biasanya memiliki tiga pandangan mengenai arti bentuk jamak ini. Adapun ketiga arti jamak ini adalah sebagai berikut: Pertama, kata ini adalah bentuk jamak yang bersifat politeistik; yaitu, aslinya kata ini memiliki pengertian suatu Allah yang jamak dan belakangan memperoleh arti Tritunggal; Kedua, kata ini berbentuk jamak yang

\footnotetext{
${ }^{30}$ Robert P. Lightner, Evangelical Teology A Survey and Review (Grand Rapids, Michigan: Baker Book House, 1986), 47.
}

Trinitarian. Yaitu, Allah Esa yang berpribadi tiga tanpak, atau paling sedikit diisyaratkan. Kejamakan ini mungkin memberi tempat bagi wahyu berikutnya tentang Trinitas; Ketiga, kata ini adalah bentuk jamak yang penuh keagungan. Bentuk jamak yang agung ini menunjukkan kebesaran dan supremasi Allah yang tak terbatas. $^{31}$

Penggunaan nama jamak untuk Allah Elohim, banyak kali dipergunakan dalam PL (Ul. 6:4). Selanjutnya gelar jamak lain yang digunakan untuk Allah dapat dilihat dalam (Pkh. 12:1 dan Yes. 54:5). Lebih lanjut lagi kata ganti orang jamak juga diperuntukkan bagi Allah sebagaimana yang diungkapkan dalam (Kej. 1:26; 3:22; 11:7; dan Yes. 6:8).

Penyajian yang lebih jelas tentang ketiga oknum ke-Allahan dapat dilihat dalam Yesaya 48:16 dan 63:7-10. Tiga oknum yang terpisah terdapat dalam bagian itu. Prainkarnasi Kristus menyatakan (Yes. 48:16), dan Allah, malaikat dihadirat-Nya dan Roh Kudus secara khusus disebutkan (Yes. 63:7-10).

\section{Bukti Perjanjian Baru (PB)}

Sebagaimana telah dikatakan pada bagian sebelumnya, bahwa kata Tritunggal tidak muncul dalam PL atau PB, akan tetapi wahyu atau penyataan doktrin tersebut sangatlah jelas dalam Perjanjian Baru.

Adapun bukti Bapa diakui sebagai Allah, dalam beberapa ayat tidak ada perbantahanya (Yoh. 6:27; 1 Ptr. 1:2). Selanjutnya Yesus Kristus diakui sebagai Allah. Ia sendiri menyatakan sifatsifat yang hanya dimiliki Allah, misalnya: mahatahu (Mat. 9:4), mahakusa (Mat. 28:18), mahahadir (Mat. 28:20). Ia (Yesus Kristus) juga melakukan perkara-perekara yang hanya dapat dilakukan oleh Allah, seperti: mengampuni dosa (Mrk. 2:1-12), membangkitkan orang mati (Yoh. 12:9). Pada bagian lain bahwa PB menegaskan pekerjaan-pekerjaan yang hanya dapat dilakukan oleh Allah, misalnya penciptaan (Yoh 1:3) dan penghakiman dimasa depan (Yoh. 5:27). Lebih lanjut lagi, Roh Kudus juga diakui Allah. Hal ini dibuktikan bahwa Ia (Roh Kudus) disebut juga

\footnotetext{
${ }^{31}$ Ryrie, Teologi Dasar I, 61.
} 
Allah (Kis. 5:3-4), Ia memiliki sifat yang hanya ada pada Allah, misalnya Mahatahu (1Kor. 2:10), Mahahadir (1Kor. 6:19), dan Ia melahirkan kembali orang-orang (Yoh. 3:5-6, 8), suatu pekerjaan yang lain dari pada yang lain dari Allah.

Menanggapi ketiga pribadi, Bapa, Anak, dan Roh Kudus, kaum injili menyatakan bahwa setiap anggota dalam ke-Allah-an secara utuh dan sama dalam hal sifat keilahian. Kemungkinan bukti yang jelas penting dan paling kuat untuk ajaran Tritunggal dalam PB ditemukan dalam ajaran Kristus. Percakapan tentang tempat Juruselamat (Yoh. 14:1-16, 33). Sangat dipenuhi dengan bukti Tritunggal. Bahwa Juruselamat (Kristus) dibedakan dari Bapa, kepada siapa Ia berdoa dan dari Roh Kudus, yang Ia janjikan untuk datang dan melanjutkan tugas-Nya. Meskipun ketiganya merupakan oknum yang terpisah tetapi pada intinya ketiga-Nya adalah satu (Yoh. 17:1-26).

Pada akhirnya, mengenai keberadaan ketiga oknum dari ke-Allahan sebagaimana ditemukan dalam bagian berikut ini, "Dan Aku (Kristus) akan berdoa kepada Bapa, dan Dia akan memberikan kepadamu seorang penenang (Roh) yang akan tinggal bersamamu sampai selamalamanya (Yoh. 14:16)." Selanjutnya Chris Marantika melalui karyanya berjudul Kristologi, mengatakan: "Keberadaan-Nya di dalam Tritunggal antara lain; Elohim (Kej. 1:1; Yes. 6:8) Melekh Yahweh (Kej. 22:11; 15-16). Bapa, Anak dan Roh adalah Allah (Yoh. 6:26; Ibr. 1:8; Kis. 5:3-4) ketiga pribadi dihubungkan secara sama dan sederajat (Mati. 28:19 dan 2 Kor. $13: 14)^{32}$

Sebelum lebih jauh menguraikan sub judul ini, berikut beberapa pengantar yang kiranya dapat menambah wawasan serta melalui pemahaman ini dapat menjadi jembatan penting untuk memberikan jawaban terhadap topik Allah yang Esa memperkenalkan diri sebagai Tritunggal.

\footnotetext{
${ }^{32}$ Chris Marantika, Kristologi (Yogyakarta: Iman Press,
} 2008).

\section{Tritunggal Dalam Ajaran Agama Lain}

Pada bagian tritunggal ini akan diuraikan beberapa sub judul yakni ajaran yang dipahami dalam ajaran agama lain.

Istilah tritunggal sebenarnya terdapat juga di dalam ajaran agama-agama lain, walaupun terdapat perbedaan-perbedaan yang mencolok. Berikut ini beberapa agama yang mengajarkan tentang istilah tritunggal tersebut, yakni dalam ajaran agama Hindu, agama Budha serta agama Pangestu.

\section{Ajaran Agama Hindu}

Istilah Tritunggal dalam kepercayaan agama Hindu lebih dikenal dengan sebutan yang lain. Tetapi prinsipnya tidak berbeda yakni, bahwa dalam ajaran Hindu memercayai adanya tiga dewa.

Harun Hadiwijoyo mengatakan: "Ketiga dewa tersebut adalah, Brahma, Wisnu, dan Siwa, yang disembah sebagai Trimurti." 33 Penting juga dipahami bahwa istilah tersebut baru menjadi umum kira-kira abad kelima Masehi.

Adapun ketiga dewata yang lain itu memiliki tugas masing-masing. Tugas dan kekuasaan atau otoritas ketiga dewata adalah sebagai berikut: "Brahma sebagai pencipta, Wisnu sebagai pemelihara dan Siwa sebagai perusak." 34

\section{Ajaran Agama Budha}

Istilah tritunggal dalam kepercayaan agama Budha dikenal dengan sebutan trikaya. Pada prinsipnya dalam ajaran agama Budha, berpendapat bahwa: "Ajaran tentang trikaya mempersatukan Budha yang bermacam-macam. Tiap Budha mendapat bagian dari pada tabiat trikaya itu." 35

Adapun ketiga Budha yang dimaksud yaitu tubuh Dharmakaya, Sambhogakaya dan Nirwanakaya. Selanjutnya penting diketahui bahwa pada hakekatnya Budha yang sebenarnya

\footnotetext{
${ }^{33}$ Harun Hadiwijono, Agama Hindu dan Budha (Jakarta: BPK. Gunung Mulia, 1987), 28.

${ }^{34}$ Harun Hadiwijono, Kebatinan dan Injil (Jakarta: BPK. Gunung Mulia, 1987), 67.

${ }^{35}$ Hadiwijono, Agama Hindu, 73.
} 
adalah Budhi, pencerahan atau orang yang sudah diterangi. Sebagaimana yang dipahani oleh Siddharta Gautama yang menjadi Budha pertama.

\section{Ajaran Agama Pangestu}

Istilah tritunggal juga dikenal dalam ajaran agama Pangestu (Kebatinan). Para anggota Pangestu sangat yakin bahwa hanya ada satu Tuhan yang wajib disembah. Hal ini sebagaimana ditegaskan dalam Serat Sasangka Jati dikatakan demikian: "Sesungguhnya Tuhan itu hanya satu yang wajib disembah, tiada Tuhan yang disembah kecuali Allah, dan Allah itulah tempat sesembahan yang sejati." 36

Disamping mempunyai Allah Yang Esa kalangan Pangestu mengakui dan meyakini bahwa Allah Yang Esa itu disebut juga Tri Purusa yang selanjutnya diterangkan sebagai keadaan yang satu bersifat tiga, sebagaimana yang dikatakan Harun Hadiwijono sebagai berikut:

\section{Adapun keadaan Tuhan yang maha Esa itu disebut: TRI PURUSA, artinya keadaan satu yang bersifat tiga, yaitu: 1. Suksma Kawakeus (Tuhan yang sejati), bahasa Arabnya: AL-LAH TA'ALA. 2. Suksma sejati (Panutan sejati-panutan sejati, guru sejati), utusan Tuhan. 3. Roh suci (manusia sejati), ialah manusia yang sejati. ${ }^{37}$}

Menurut pernyataan ini Allah yang esa atau yang maha esa itu bersifat tiga. Selanjutnya kata "sifat" oleh sebagian pengikut Pangestu diterangkan sebagai "faset" atau "aspek," segi, muka. ${ }^{38}$

Adapun suksma kawekas berarti suksma yang mulia, yang menguasai hidup atau Tuhan hidup. Suksma sejati berarti yang sebenarnya menghidupkan, dan yang dihidupkan adalah Roh suci, yaitu Roh Allah atau jiwa manusia. Jadi dapat disimpulkan bahwa ketiga fase itu dikatakan sebagai yang menguasai hidup, yang menghidupkan dan yang dihidupkan.

Memperhatikan istilah Tritunggal dalam ajaran beberapa agama tersebut, secara umum

\footnotetext{
${ }^{36}$ Tim Penyusun: "Pangestu," Serat Sasangka Jati (Surakarta: Terbitan Pangestu, 1964), 108.

${ }^{37}$ Hadiwijono, Kebatinan, 67.

${ }^{38}$ Ibid.
}

dapat dimengerti bahwa istilah Tritunggal tersebut memiliki kesamaan secara literal. Misalnya dalam ajaran agama Hindu yang dikenal dengan tiga dewa (Brahma, Wisnu dan Siwa), disebut Trimurti. Selanjutnya dalam ajaran Budha yang dikenal dengan sebutan Trikaya. Lebih lanjut lagi dalam ajaran Pangestu, mereka memahami bahwa hanya ada satu Allah yang patut disembah dan Allah Yang Esa itu mereka sebut dengan istilah popular yaitu Tripurusa (Suksma Kawekes, Suksma Sejati dan Roh Suci).

\section{Kemungkinan Pengenalan akan Allah Yang Esa}

Pada awal tulisan ini telah disingung ungkapan Ayub, "Dapatkah engkau memahami hakekat Allah, menyelami batas-batas kekuasaan yang Mahakuasa? (Ayb. 11:7).” Selanjutnya menanggapi hal yang sama nabi Yesaya juga pernah berkata, "Jadi dengan siapakah hendak kamu samakan Allah, dan apa yang dapat kamu anggap serupa dengan Dia (Yes. 40:18).”

Tuhan Yesus Kristus suatu saat pernah berkata kepada Filipus, "barangsiapa telah melihat Aku ia telah melihat Bapa (Yoh. 14:9; Ibr.1:3)" Yesus Kristus menyatakan Allah kepada kita karena Dia sendiri adalah Allah (Yoh.1:1).

Mengamati dua bagian Firman Tuhan di atas dapat dipahami bahwa Allah Yang Esa itu adalah satu pribadi yang tidak dapat di jangkau. Bahkan dalam iman Kristen sangat jelas dan tegas mengajarkan, bahwa batasan yang dimaksud adalah dalam pengertian, oleh karena pengertian manusia yang sangat terbatas. Tetapi pada sisi yang lain, orang Kristen selalu di ajar juga untuk mengingat apa yang diajarkan oleh Tuhan Yesus Kristus, sebagaimana yang pernah dinyatakanNya, "Inilah hidup yang kekal itu, yaitu bahwa mereka mengenal Engkau, satu-satu-Nya Allah yang benar, dan mengenal Yesus Kristus yang telah Engkau utus (Yoh. 17:3)." Apabila menghubungkan bagian-bagian Firman Tuhan di atas, maka terkesan bahwa Firman Tuhan atau Alkitab ada yang bertentangan atau kontras. Tetapi yang sebenarnya tidaklah demikian sebaliknya Firman Tuhan itu benar-benar 
diilhamkan Allah dan saling mendukung satu sama dengan yang lain.

Orang Kristen patutlah bersyukur dengan kenyataan bahwa Anak Allah telah datang dan telah mengaruniakan pengertian kepada kita, supaya kita mengenal yang benar, di dalam anakNya Yesus Kristus sebab Dia adalah Allah yang benar. Di dalam Dialah ada keselamatan yang kekal, keselamatan yang sejati. Dengan perkataan lain bahwa Allah Yang Esa itu dapat kita kenal, walaupun pengertian manusia terbatas untuk menjangkau Dia.

Bagaimana formula supaya dapat mengenal Allah Yang Esa? Adakah syarat yang harus dipenuhi agar dapat mengenal Dia? Adalah hal yang sangat menarik untuk membahas pertanyaan-pertanyaan tersebut? karena itu mari menyimak uraian berikut ini.

Satu hal penting untuk dimengerti kaum Kristen, bahwa Allah Yang Esa mengkomunikasikan diri-Nya sendiri kepada manusia sebagai ciptaan-Nya yang paling sempurna. Selanjutnya hal yang menarik perhatian bahwa fakta teologi setiap orang memiliki pengetahuan tentang Allah Yang Esa, walaupun pemahaman yang dimiliki berbeda-beda. Sebagaimana dimaklumi dalam dunia ilmu pengetahuan pada umumnya, manusia meletakakan dirinya di atas objek penelitiannya dan secara aktif mengesampingkan pengetahuannya sendiri oleh metode apapun yang tampaknya paling sesuai, sebaliknya dalam menggumuli bidang teologi ia tidak berdiri sendiri di atas objek pengetahuannya tetapi justru berdiri di bawah obyek yang ditelitinya. Dengan perkataan lain, bahwa manusia hanya dapat mengenal Allah Yang Esa sejauh Allah Yang Esa sendiri secara aktif memperkenalkan diri-Nya. Menganggapi hal ini Barth mengatakan, "bahwa manusia dapat mengenal Allah hanya jika Allah datang kepada manusia melalui wahyu-Nya." ${ }^{39}$

Penting ditekankan dan dipertahankan bahwa teologi tidaklah mungkin ada jika Allah Yang Esa tidak mewahyukan dirinya sendiri. Apabila berbicara tentang wahyu, harus disadari bahwa bukan berarti Allah Yang Esa berada dalam keadaan yang pasif, tetapi justru Allah

\footnotetext{
${ }^{39}$ Berkhof, Teologia Sistematika, 38.
}

Yang Esa sendiri yang secara aktif menjadikan diri-Nya dikenal. Selanjutnya tidak ada satu pun yang mengejutkan dalam kenyataan bahwa Allah Yang Esa hanya dapat dikenal sejauh Dia sendiri yang memperkenalkan diri-Nya.

Rasul Paulus adalah rasul yang dikenal sebagai penulis beberapa surat kepada jemaat yang pernah dilayaninya, antara lain berkata: "Siapakah gerangan diantara manusia yang tahu, apa yang terdapat di dalam diri manusia, selain roh manusia sendiri yang ada di dalam dia? Demikian pulahlah tidak ada orang yang tahu apa yang terdapat dalam diri Allah selain roh Allah" (1 Kor. 2:11). Perkataan Rasul Paulus ini mengantarkan umat Kristen kepada suatu pengertian yang jelas dan tegas bahwa Roh Kudus-lah yang menyelidiki segala sesuatu, bahkan sampai hal-hal yang terdalam mengenai Allah Yang Esa dan selanjutnya menyatakan kepada manusia. Jadi, Allah-lah yang telah membuat atau memproklamasikan diri-Nya untuk dikenal. Adapun pengetahuan manusia tentang Allah diturunkan melalui wahyu-Nya sendiri melalui alam ciptaaan-Nya maupun melalui Alkitab atau Firman Allah. Menganggapi hal ini, para punjangga dan para penulis riwayat hidup, para teolog, dan para ahli pidato mengakui bahwa "ketidaksanggupan mereka untuk menguraikan kemuliaan dan kesempurnaan Allah Yang Esa, sang penyelamat manusia yang terpuji itu." ${ }^{40}$

Setelah memahami bahwa Allah Yang Esalah yang memprakarsai pengenalan akan diri-Nya maka sebagai orang Kristen, hal tersebut merupakan prinsip yang sangat penting dan mendasar. Harus diakui bahwa sejak dini kita memiliki pengetahuan tentang Allah Yang Esa, yang diperoleh sejak dini dan ada juga pengenalan tentang Allah Yang Esa diperolehnya sebagai proses dalam perjalanan kehidupannya. Biasanya orang membedakan antara pengetahuan yang dimilikinya sejak lahir dan pengetahuan yang dimiliki sebagai proses kehidupannya. Namun perbedaan ini bukanlah perbedaan yang sangat logis yang bisa dibilang ketat, sebab pada umumnya pengetahuan

${ }^{40}$ John F. Walvoord, Yesus Kristus Tuhan Kita (Surabaya: Yakin, t. t.), 5. Memperkenalkan diriNya 
manusia yang diperoleh melalui proses kehidupannya yang sistematis.

Bagi kaum Kristen memahami bahwa pengenalan akan Allah Yang Esa melalui penyataan atau wahyu. Bahwa dunia disekeliling kita masih dapat kita kenal. Tubuh manusia, batang pohon, proses kimia masih dapat diselediki dan dipahami berdasarkan pengetahuan. Hati manusia dapat kita selami sedikit demi sedikit; untuk mengetahui apa yang terkandung di dalamnya maka perlu melalui proses. Akan tetapi mengenai Allah mungkinkah Dia dipersoalkan? Adakah suatu cara untuk memahami, menyelidiki dan menyelami keberadaan dari pribadi dari Allah Yang Esa? Memang, sebenarnya tidak mungkin kita berbicara tentang Dia. Baik juga dari permulaan dicamkan sedalam-dalamnya. Hanya satu yang mengenal Allah secara tuntas, yakni Dia sendiri. Tidak seorangpun mengenal Allah, kecuali Allah sendiri yang berinisyatif memperkenalkan atau menyatakan diriNya.

Pengertian atau akal manusia sangat terbatas untuk mengenal Allah, namun Allah Yang Esa yang hidup dan benar itu sungguh ajaib. Dialah sebab yang tidak ada penyebabnya. Adakah cara manusia mengenal Dia? Dalam ajaran atau iman Kristen mengajarkan bahwa Allah telah menyatakan dirinya pada masa lampau dan Allah juga menyatakan diri kepada kita sekarang. B.J. Boland mengatakan hubungan dengan hal itu bahwa, "perbuatan Allah disebut penyataanNya." ${ }^{41}$ Selanjutnya penting ditegaskan bahwa kesaksian perbuatan Allah Yang Esa itu dicatat di dalam Alkitab yang menjadi dasar segala sesuatu yang berhubungan dengan iman Kristen.

Sebelum mengenal Allah Yang Esa, maka syarat penting untuk dimiliki yakni memahami atau meyakini Firman Allah atau Alkitab. Allah pada masa lalu telah berinisiatif memperkenalkan diriNya melalui Alkitab. Adapun istilah "penyataan" ini adalah sebagai terjemahan dari kata kerja latin, yaitu revelare, dan kata bendanya adalah revelatio (bandingkan bahasa Inggrisnya "revelation"). Bahasa Ibraninya kata kerjanya "gillah", dan bahasa Yunaninya

${ }^{41}$ B. J. Boland, Intisari Iman Kristen (Jakarta: BPK Gunung Mulia, 1980), 17. yakni "apokalypto". Semua kata kerja tersebut berisi pengertian seperti yang dikatakan G.C. Niftrik, sebagai berikut:

Pernyataan artinya menyingkapkan atau membuka selubung, menunjukan yang tersembunyi, memberitaukan apa yang tidak di kenal, jadi katakata itu adalah mengenai hal-hal yang tidak diketahui dan tersembunyi. ${ }^{42}$

Kadang-kadang sehubungan dengan hal ini, orang menggunakan dan mengganti dengan kata "wahyu" kata kerja dalam Bahasa Arab yang artinya "mengilhamkan" atau membisikkan sesuatu kepada seseorang. Bisa kepada nabi atau rasul yang ditetapkan Allah sendiri.

Berhubungan dengan pernyataan Allah Yang Esa, menurut sejarah ada dua cara Dia (Allah) mengambil prakasa untuk menyatakan diri-Nya. Cara-cara yang dimaksud adalah melalui penyataan umum dan khusus. Menanggapi pengertian dua cara dari Allah Yang Esa, Charles C. Ryrie berpendapat bahwa:

Penyataan umum mencakup segala yang dinyatakan Allah di dalam dunia sekitar kita, yakni semua ciptaanNya termasuk manusia; sedangkan penyatan khusus mencakup berbagai cara yang dipakai Allah untuk menyampaikan wahyu-Nya yang disusun dalam/melalui Alkitab. Penyataan umum kadangkadang disebut teologi Naturalis dan penyataan khusus disebut teologi yang diwahyukan. ${ }^{43}$

Adapun yang dimaksud dengan penyataan umum adalah dalam pengertian yang benarbenar umum, baik jangkauannya juga sisi geografisnya adalah meliputi seluruh dunia. Hal mana disebabkan karena pernyataan ini adalah mengenai semua orang dimanapun mereka berada. Selanjutnya, yang di maksud dengan pernyataan khusus adalah dalam pengertian yang prinsipnya terbatas pada Alkitab sebagai firaman Allah sendiri. Penting sekali dimaklumi bahwa pernyataan khusus itu sebenarnya menyebut penyataan yang umum itu. Salah satu contoh yang nyata sebagaimana yang pernah

${ }^{42}$ G. C. Van Niftrik dan B. J. Boland, Dogmatika Masa Kini (Jakarta: Gunung Mulia, 1984), 57.

${ }^{43}$ Charles C. Ryrie, Teologi Dasar I, (Yogyakarta: Yayasan ANDI, 1992), I: 37. 
diungkapkan Daud dalam salah satu Mazmurnya menuliskan "Langit menceritakan kemuliaan Allah, dan cakrawala memberitakan pekerjaan tangan Nya; hari meneruskan berita itu kepada hari dan malam menyampaikan pengetahuan itu kepada malam" (Maz. 19:2-3).

Lebih lanjut lagi menanggapi arti penyataan khusus, Derek Prime menandaskan: "Pernyataan khusus artinya penyataan yang tidak mungkin sampai kepada manusia dengan penyelidikan alam, olehnya atau dengan memakai akalnya sendiri." ${ }^{44}$ Allah Yang Esa tidak saja menyatakan atau mewahyukan suatu ajaran. Firman Allah tidak saja berupa sebuah Alkitab, melainkan menjadi Manusia. Jadi penyataan Allah bukannya "sesuatu" melainkan "seseorang," namanya adalah Yesus Kristus. Demikianlah Allah menyatakan diri-Nya sendiri. Sebagaimana pada bagian terdahulu telah disinggung bahwa Tuhan Yesus sendiri pernah berkata: "Barangsiapa telah melihat Aku, ia telah melihat Bapa (Yoh. 14:9).” Menanggapi maksud bagian ini bahwa dengan memandang kepada Tuhan Yesus Kristus serta mengaminkan eksistensi serta pekerjaan-Nya sesungguhnya mengertilah kita siapa dan bagaimana Dia sebenarnya dihadapan manusia.

Yesus Kristus disalibkan dan dibangkitkan adalah untuk keselamatan manusia yang berdosa. Selanjutnya dalam pekerjaan Kristus itulah tersimpul segala sesuatu yang hendak Allah katakan kepada kita, oleh karena itu Yesus Kristus disebut Firman Allah.

Harus diakui bahwa untuk mengenal Allah Yang Esa merupakan suatu kemustahilan, amat terlebih jika konsep dasar pemahaman kita dilandaskan atas pikiran manusia, tetapi bukan berarti karena sukar lalu sama sekali tidak bisa. Allah sendiri yang memprakarsainya yakni melalui penyataan umum dan penyataan khusus dari Allah sendiri.

Satu prinsip yang penting bahwa pengenalan secara teori tentang Allah Yang Esa sebagai Tritunggal tidak berbanding lurus dengan pemahaman secara rohani, dalam kasus tertentu seringkali secara teori mungkin masih kurang

\footnotetext{
${ }^{44}$ Derek Prime, Pertanyaan Tentang Iman Kristen Dijawab dari Alkitab (Jakarta: Yayasan Komunikasi Bina Kasih/OFM, 1988), 17.
}

namun secara rohani akan menjamin pengenalan tentang eksisitensi pribadi dari Allah Yang Esa.

\section{KESIMPULAN}

Alkitab menyatakan bahwa Allah yang Esa sukar bahkan mustahil untuk dipahami (Ayb. 11:7; Yes. 40:18), namun secara nyata bahwa Allah Yang Esa dapat dikenal. Tuhan Yesus pernah menegaskan kebenaran penting tesebut kepada murid-murid-Nya: "Sekiranya kamu mengenal Aku, pasti kamu menganal Bapa-Ku. Sekarang ini kamu mengenal Dia dan kamu telah melihat Dia (Yoh. 14:7).” Mengapa Allah yang Esa itu sukar dipahami? Karena masalah dosa, pikiran, pengetahuan dan bahasa manusia yang terbatas. Namun bukan berarti manusia tidak dapat mengenal Allah.

Pemahaman tentang Allah yang Esa dalam ajaran Kristen merupakan hal yang menantang. Adapun hasil kajian tulisan ini, bahwa eksistensi Allah Yang Esa dalam ajaran Kristen sangat jelas karena dilaporkan Alkitab, dengan kata lain bahwa dalam Alkitab Allah Yang Esa memperkenalkan diri-Nya; selanjutnya bahwa Allah Yang Esa yang telah memperkenalkan diri sebagai Allah Tritunggal yakni Bapa, Anak (Yesus Kristus), dan Roh Kudus sangat jelas berdasarkan PL maupun PB. Allah Yang Esa sebagai Tritunggal ketiga-Nya sehakekat sekaligus setara. Akhirnya, bahwa setiap orang pasti dapat mengenal Allah Yang Esa sejauh yang dikatakan dala Alkitab.

Kunci memahami dan mengenal Allah yang Esa yakni terlebih dahulu meyakini Alkitab adalah Firman Allah. Kiranya pemahaman yang dimiliki setiap orang percaya dapat memberi makna secara pribadi, bagi orang lain, dan akhirnya di atas kedua kepentingan tersebut kemuliaan dan hormat bagi hanya bagi Allah Yang Esa saja. 


\section{KEPUSTAKAAN}

Alkitab Penuntun Hidup Berkelimpahan Seri: Life Aplication Study Bible. Malang: Gandum Mas, Cet. II, 2016.

Berkhof, Louis dan Enklaar, I. H. Sejarah Gereja. Jakarta: BPK. Gunung Mulia, 1992.

Berkhof, Louis. Teologia Sistematika Doktrin Allah. Jakarta: Lembaga Reformed Injili Indonesia, 1994.

Biblia Hebraica Stutgartensia, Stuttgart: Deutsche Biblegesellchaft, 1990.

Boland, B. J. Intisari Iman Kristen. Jakarta: BPK. Gunung Mulia, 1980.

Brill, J. Wesley. Dasar Yang Teguh. Bandung: Yayasan Kalam Hidup, 1994.

Buswell, James Oliver A Systematic Teology of The Christian Religion (Grand Rapids: Zondervan Publishing House, 1978.

Crossley, Robert. Tritunggal Yang Esa. Jakarta: Yayasan Komunikasi Bina Kasih/OMF, 1992).

Departemen Pendidikan dan Kebudayaan. Kamus Besar Bahasa Indonesia. Jakarta: Balai Pustaka, 1991.

Echlos, John M. dan Sadily, Hasan. Kamus Inggris Indonesia. Jakarta PT. Gramedia Pustaka Utama, 1993.

Finlayson R. A. dan Houston, J. M. Allah, Ensiklopedi Alkitab Masa Kini Jakarta: Yayasan Komunikasi Bina Kasih/OMF, 1994.

Frame, John M. Doktrin Pengetahuan Tentang Allah I (Objek Pengetahuan dan Justifikasi Pengetahuan. Malang: SAAT, Cet. I, 1999.

Hadiwijono, Harun. Agama Hindu dan Budha. Jakarta: BPK. Gunung Mulia, 1987. . Iman Kristen. Jakarta: BPK.

Gunung Mulia, 1995. . Kebatinan dan Injil Jakarta: BPK. Gunung Mulia, 1987.

Hoeksema, Herman Reformed Dogmatics. (Grand Rapids: Reformed Free Publishing Association, 1996.

John F. Walvoord. Yesus Kristus Tuhan Kita. Surabaya: Yakin, t. t.
Lembaga Alkitab Indonesia, Perjanjian Baru Indonesia Yunani. Jakarta: Lembaga Alkitab Indonesia, 1994.

Lightner, Robert P. Evangelical Teology A Survey and Review. Grand Rapids, Michigan: Baker Book House, 1986.

Manton, M. E. Kamus Istilah Teologia InggrisIndonesia. Malang: Gandum Mas, 1995.

Prime, Derek. Pertanyaan tentang Iman Kristen Dijawab Dari Alkitab. Jakarta: Yayasan Komunikasi Bina Kasih/OMF, 1988.

Rianse, Usman. Metodologi Penelitian Sosial dan Ekonomi (teori dan Aplikasi). Bandung: Alfabeta CV, 2008.

Suurmond, Ds. P. B. Allah Itu Berkuasa Tetapi Bagaimana? Jakarta: BPK Gunung Mulia, 1996.

Thiessen, Hendry C. Teologia Sistematika. Malang: Gandum Mas, 1993.

Tim Penyusun "Pangestu," Serat Sasangka Jati Surakarta: Terbitan Pangestu, 1964.

Tong, Stephen. Allah Tritunggal. Jakarta: Lembaga Reformed Injili Indonesia, 1993.

Van Niftrik, G. C. dan Boland, B. J. Dogmatika Masa Kini. Jakarta: Gunung Mulia, 1984.

Ryrie, Charles C. Teologia Dasar I. Yogyakarta: Yayasan ANDI., 1992.

Zaluchu, Sonny Eli. "Strategi Penelitian Kualitatif Dan Kuantitatif Di Dalam Penelitian Agama." Evangelikal: Jurnal Teologi Injili dan Pembinaan Warga Jemaat 4, no. 1 (January 31, 2020): 28. https://journal.sttsimpson.ac.id/index.ph $\mathrm{p} / \mathrm{EJTI} /$ article/view/167. 